\title{
A IMAGEM DO FILÓSOFO: O TEETETO DE PLATÃo E O MÉTODO DE SÓCRATES
}

\author{
Cesar de Alencar ${ }^{1}$ \\ Universidade Federal do Amapá (UNIFAP) \\ Universidade Federal do Rio de Janeiro (UFRJ) \\ (D) https://orcid.org/0000-0003-3145-0584 \\ E-mail: cescama@gmail.com
}

\section{RESUMO:}

Pretende-se oferecer aqui uma justificativa, tal como ela parece ter sido indicada por Platão no Teeteto, para o método de Sócrates, anunciado em Apologia como uma anthropíne sophía, capaz de avaliar os diferentes tipos de conhecimento. O recurso à imagem da maiêutica, no Teeteto, traz a representação de um aspecto desse método, posterior à refutação (élenkhos), em que o examinador ou parteiro elevam as opiniões do interlocutor até um princípio transcendente, para mostrar-lhes ou sua vacuidade ou sua solidez. Por fim, o Diálogo de Platão parece não apenas representar o método de Sócrates, mas se inspirar nele para a composição do seu discurso, que joga com a forma de fazer ver e com aquilo que se vê a partir dele.

PALAVRAS-CHAVE: Platão; Sócrates; Maiêutica; Filosofia.

\section{THE IMAGE OF THE PHILOSOPHER: THE THEAETETUS OF PLATO AND THE METHOD OF SOCRATES}

\begin{abstract}
:
It is intended to offer a justification, as it seems to have been indicated by Plato in the Theaetetus, for the method of Socrates, announced in Apologia as an anthropine sophía, able to evaluate the different types of knowledge. The recourse to the image of maieutics in the Theaetetus brings the representation of an aspect of this method, after the refutation (élenkhos), in which the examiner and midwife raises the opinions of the interlocutor until his transcendent principle, to show them or their emptiness or its strength. As we shall see, Plato's Dialogue seems not only to represent the method of Socrates, but to draw inspiration from it for the composition of his discourse, which plays with the form of seeing and with what is seen from it.
\end{abstract}

KEYWORDS: Plato; Socrates; Maieutics; Philosophy.

\footnotetext{
${ }^{1}$ Doutorando em Filosofia na Universidade Federal do Rio de Janeiro (UFRJ), Rio de Janeiro - RJ, Brasil. Professor de Filosofia da Universidade Federal do Amapá (UNIFAP), Macapá - AP, Brasil.
}

ALENCAR, Cesar de. A imagem do filósofo: o Teeteto de Platão e o método de Sócrates. Griot : Revista de Filosofia, Amargosa-BA, v.18, n.2, p.129-142, dezembro, 2018. 


\section{Proêmio ou A leitura dos Diálogos de Platão}

Dependendo de como se leia um Diálogo de Platão, os aspectos alheios ao conteúdo de teor, como se diz, propriamente filosófico podem permanecer ausentes das análises sobre o texto platônico, ou porque não se os entende como importantes, ou porque eles estariam, grosso modo, subordinados ao dito conteúdo filosófico. Por certo, os estudos mais recentes vêm, com afinco, apontar para outra direção, em que se evita o preconceito de não proceder a uma leitura dramática dos Diálogos. Como havia dito Goldschmidt, o Diálogo é ilustração viva de um método que investiga e que, com frequência, se investiga e não é senão pelo método que se deve explicar sua composição e sua estrutura filosófica ${ }^{2}$.

E o que poderia nos dizer o recurso ao método dramático do Diálogo? No Teeteto, Platão retrata de forma indireta a conversa que Sócrates teve antes de se dirigir ao pórtico real a fim de tomar ciência da acusação que Meleto havia lhe imputado (Teeteto, 210d). Sabemos ser essa a circunstância anterior aos acontecimentos descritos em outros Diálogos - especificamente os quatro textos que têm como pano de fundo o julgamento, condenação e morte de Sócrates. Já isso nos sugere bastante. Comumente posto entre os Diálogos da fase final de Platão, o Teeteto remonta aos textos considerados da fase inicial, apresentando uma imagem de Sócrates que será bem incomum entre os textos da velhice: com a exceção do Filebo, os Diálogos finais são, todos, a eloquente testemunha da perda de vigor, talvez de importância, de Sócrates no papel de condutor do exame dialógico $^{3}$.

Isso certamente significa algo. Do que nos é possível dizer, pretende-se mostrar aqui que há um jogo de lusco-fusco que permeia a obra platônica. $O$ discurso escrito,

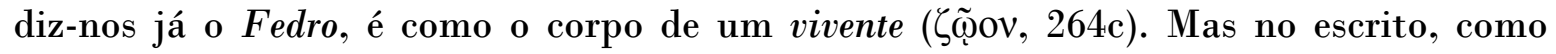
numa pintura, a vida está ausente: é preciso que as coisas de valor sejam depositadas

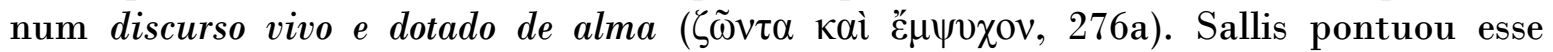
detalhe com argúcia: o lógos escrito, praticado em vista de provocar a recordação (recollection) do que se sabe (Fedro, 275d), deve estar posto a serviço desta finalidade, que é sua alma. Apontando para o fato de que o texto platônico clama por ser interpretado à luz desta reflexão sobre a escrita, Sallis não pôde senão concluir serem os Diálogos de Platão a indicação não de uma mera recriação de certas posições teóricas particulares, mas da busca por realizar o próprio filosofar ${ }^{4}$.

Ainda que Sallis apresente sua maneira de ler os Diálogos a partir da preocupação em se ater unicamente aos Diálogos, é possível traçar um paralelo entre esta

${ }^{2}$ Cf. GOLDSCHMIDT (2002), p. 3. Acerca dos estudos do paradigma literário para a análise dos Diálogos, o texto de apresentação do X International Archai Seminar: Plato's styles and characters: between literature and philosophy - 2012, disponível no site da International Plato Society, possui muito boas indicações sobre essa bibliografia mais recentes.

${ }^{3}$ Estamos aqui, naturalmente, aceitando a já clássica separação dos Diálogos em três fases - embora não seja sem problemas que ela se apresente. O Teeteto, afirma BENSON (2012), está sem maiores problemas situado na fase final da produção platônica.

${ }^{4}$ Cf. SALLIS (1975), p. 6-22

ALENCAR, Cesar de. A imagem do filósofo: o Teeteto de Platão e o método de Sócrates. Griot : Revista de Filosofia, Amargosa-BA, v.18, n.2, p.129-142, dezembro, 2018. 
reflexão do Fedro e àquela presente na Carta VII, como o fez Szlezák em seu trabalho ${ }^{5}$. Isso porque se o texto deve estar posto a serviço da recordação do que se sabe, a Carta VII parece referir-se a uma justificativa acerca desta subordinação, por assim dizer, do discurso escrito ao discurso vivo e animado, a partir da descrição positiva, tão sucinta quanto surpreendente, do que seja o conhecimento (epistéme) e como ele vem a ser. Esta conhecida passagem da digressão sobre o saber e a escrita na Carta VII sugere que se tomem os textos de Platão enquanto vinculados a uma noção do saber como opinião verdadeira inteligida nas coisas, a surgir e se instalar na alma como uma visão das coisas pela fricção constante entre si dos quatro elementos descritos abaixo (344b).

Há em cada um dos seres três [elementos], a partir dos quais é necessário que o saber [epistéme] surja, sendo o quarto ele mesmo [ou seja, epistéme]; em quinto lugar, há que pôr o que é em si cognoscível e verdadeiramente é. Um é o nome, o segundo, a definição, o terceiro, a imagem, o quarto, o saber. (...) 0 quarto é o saber, a inteligência e a opinião verdadeira sobre ele. Ora, essa unidade [entre epistéme, noûs e alétheia dóxa] deve ser posta não em sons, nem em formas de corpos, mas deve ser presente nas almas; (...) sendo o ser e a qualidade dos entes, e procurando a alma conhecer não a qualidade de algo, mas o ser, cada um desses quatro modos estende-se à alma, por palavras e fatos, cada um mostrando-se tanto pelo que diz, quanto pelo que indica, facilmente refutável pelas sensações - cada um deles enche todo homem, para dizer em uma palavra, de aporia. (tradução de J. Trindade dos Santos; 342a$343 \mathrm{c})$.

Aqui a epistéme, ela também um elemento corpóreo, por assim dizer, é facilmente refutável pelas sensações. A phrónesis e o noûs que fazem brilhar na alma o saber de quinto tipo são, quanto a isso, distintos da epistéme: assim se entende em que medida deve-se trazê-lo não em sons ou em formas de corpos, mas na alma. É por esse motivo que o texto, naturalmente débil (343d), não pode ser repositório do saber, como o Fedro

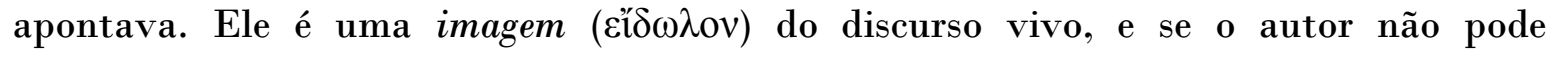
apresentar nada de maior valor que aquilo que pôs a escrito, ele é poeta e não filósofo (Fedro, 278d-e).

Se isso pode nos orientar à leitura dos Diálogos de Platão, teremos de aceitar que há uma camada textual que diz respeito ao modo (Goldschmidt diria método) pelo qual o autor nos faz ver aquilo sobre o quê dialogam suas personagens. O sobre o quê está sempre para além do texto. O que é inteligido nas coisas, diz-nos a Carta VII, é um ver, não um dizer. No Teeteto, ao pôr-se em questão a resposta possível à pergunta o que é o saber, o autor parece indicar, pelo transcurso do diálogo, alguma possível intelecção sobre este algo que está em questão, algo de que o discurso não pode dar conta por sua debilidade. Se Sallis tem razão, o Teeteto põe à vista o próprio processo de buscar respostas. A distinção entre aquilo pelo qual Platão faz ver e aquilo que de fato ele faz ver, sugiro, é a que está presente entre os quatro elementos, do dizer, e o quinto elemento, da intelecção.

${ }^{5}$ SZLEZÁK (2009), p. 382-397

ALENCAR, Cesar de. A imagem do filósofo: o Teeteto de Platão e o método de Sócrates. Griot : Revista de Filosofia, Amargosa-BA, v.18, n.2, p.129-142, dezembro, 2018. 
Confiar nessas indicações é ter em mãos uma maneira de ler os textos platônicos, uma forma de ver as intenções deste autor que jamais se apresenta nos Diálogos. O jogo de lusco-fusco entre ver e dizer parece um elemento fundamental da obra platônica. $\mathrm{O}$ próprio Teeteto, porém, prima por nos mostrar Sócrates justificando seu filosofar exatamente como um processo de dar à luz ao saber. Enquanto um parteiro de ideias, Sócrates tece a imagem do filósofo e da filosofia como uma forma de fazer ver o saber na própria alma daquele que sabe. $O$ que proponho é demonstrar no Teeteto a similaridade entre a maneira de fazer ver dos Diálogos, como vimos, e à maneira de fazer ver da prática socrática, como maiêutica: não para sustentar a tese de que os Diálogos são a tentativa de Platão reproduzir o método de Sócrates - antes, para mostrar como Platão teve em Sócrates o ponto de partida para o seu próprio método.

\section{Teodoro ou 0 pano de fundo da cena dramática}

O Diálogo Teeteto foi escrito - e é como texto que se dá inclusive na sua dinâmica dramática. Euclides, a quem Terpsião encontra e fica sabendo sobre a doença de Teeteto, e também sobre a conversa de há tempos, quando Sócrates estava vivo e Teeteto tinha sido predestinado a se tornar homem célebre, se chegasse a ser homem (142d), informa-o de que Teeteto vive. Uma vida honrosa é mesmo o que se esperaria de alguém a quem Sócrates, agora morto, elogiara a bela natureza. $O$ autor da profecia, tão importante quanto seu objeto, estivera na ocasião em diálogo, sobre o qual Euclides trabalhou incansavelmente.

\footnotetext{
Logo que cheguei a casa, tomei alguns apontamentos sobre o que mais me impressionara, havendo posteriormente redigido mais de estudo o que me acudia à memória. Além do mais, sempre que ia à Atenas, interrogava Sócrates acerca do que não me recordava com minúcias e, de regresso, corrigia meu trabalho. Foi assim que, praticamente, consegui reproduzir todo o diálogo. (As traduções do Teeteto são de Carlos Alberto Nunes, com alterações pontuais; 142d-143a).
}

Euclides foi um socrático, de quem sabemos bem pouco. O suficiente, porém, para entendermos seu valor e sua proximidade a Platão: conta-nos Diógenes Laércio que, após a morte de Sócrates, alarmados com a crueldade dos tiranos, os filósofos foram abrigar-se em exílio na companhia de Euclides em Mégara ${ }^{6}$. Os megáricos, como ficaram conhecidos por sua causa, foram no fim chamados de dialéticos, por exporem seus lógoi na forma de perguntas e respostas, como Sócrates fizera. Não é outra a forma predominante dos escritos platônicos. É como dialético que se apresenta o escrito de Euclides sobre a conversação travada entre Sócrates e Teeteto. O escrito de Platão, que

${ }^{6} \mathrm{DL}, \mathrm{II}, 106$.

ALENCAR, Cesar de. A imagem do filósofo: o Teeteto de Platão e o método de Sócrates. Griot : Revista de Filosofia, Amargosa-BA, v.18, n.2, p.129-142, dezembro, 2018. 
o reproduz, no fundo é a mímesis da mímesis do texto de Euclides - tomado, explica o próprio Euclides, enquanto um diálogo direto ${ }^{7}$.

Porém, redigi de tal modo o diálogo, que em vez de Sócrates me relatar o ocorrido, como o fez, entretém-se com os que ele próprio declarou terem tomado parte na conversa. Referia-se ao geômetra Teodoro e a Teeteto. Para não sobrecarregar o escrito com tantas fórmulas intercaladas no discurso, sempre que Sócrates fala: digo, ou afirmo ou, com referência aos interlocutores: concordou, não concordou, dei ao trabalho feição de um diálogo direto entre ele e os dois opositores, com exclusão de tudo aquilo. (143b-c).

Em diálogo direto, Teodoro é chamado a depor sobre quem de seus jovens alunos de geometria, seus alunos de Atenas, não de Cirene, se faz digno de menção (143d-e). Não demora a que Teodoro se atenha ao caso de Teeteto, um belo rapaz que nada tem de belo, é verdade, sendo muito parecido com Sócrates até: de natureza maravilhosa $(\theta \alpha v \mu \alpha \sigma \tau \tilde{\omega} \varsigma \varepsilon \tilde{\tilde{~}} \pi \varepsilon \varphi v \kappa o ́ \tau \alpha)$, tem boa memória, uma docilidade e coragem únicas. Seu caráter parece livre dos problemas excessivos que acometem os que, (a) de entendimento rápido e boa memória, costumam ser dados a ações impulsivas e não corajosas; e os que, (b) mais ponderados, são preguiçosos e esquecidos. Teeteto, em sua beleza de caráter que o aproxima de Sócrates, tem avançado com afinco e segurança rumo ao aprendizado e à

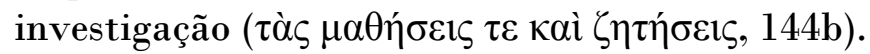

Teeteto é então chamado para junto de Sócrates, e o filósofo não demora a examinar se o que disse Teodoro era verdade: quer dizer, se havia alguma semelhança física entre sua feiura e a do jovem aluno. A forma socrática de examinar está em certificar-se se quem fala sabe do assunto sobre o qual faz afirmações (no exemplo do Diálogo: se entende de música; 144e). Teodoro não é pintor, mas sua avaliação sobre a alma é de mais valor que sua afirmação sobre fisionomia: por ser entendido das coisas relativas à educação ( $\pi \alpha 1 \delta \varepsilon i ́ \alpha \varsigma)$, seu elogio a Teeteto, que o aproximou de Sócrates

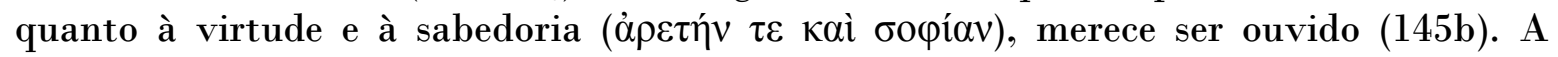
autoridade de Teodoro em falar da semelhança de alma entre Sócrates e Teeteto é traduzida rapidamente como oportunidade para o exame da alma do jovem. Mas pela identificação, não deveria Sócrates também ser examinado? Por que razão o diálogo se coloca, diz Sócrates a Teeteto, como o momento de te exibires e eu de te examinar (445b)?

A identificação de Sócrates e Teeteto atende a uma dinâmica do diálogo. A cena que põe início ao exame revela um jogo que se estenderá, e que diz respeito à relação entre mestre e aluno, ou entre quem sabe e quem não sabe. Não por acaso, a pequena

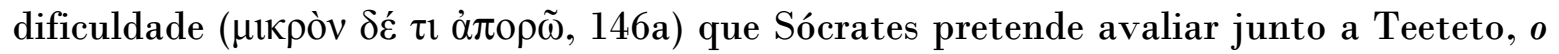

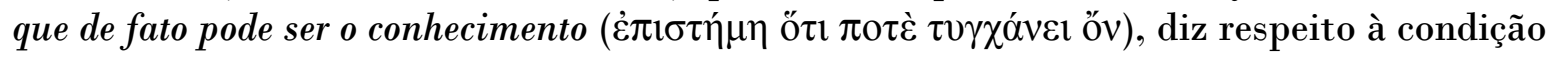
mesma em que o jovem é de algum modo um sabedor: como aluno, ele sabe, melhor

\footnotetext{
${ }^{7}$ Não seria casual mencionar aqui o papel atribuído ao discurso direto na República (393c) como imitação, discurso este que atende à intenção de assemelhar-se o mais possível o seu estilo ao da pessoa cuja fala imita. Se o texto de Euclides se esmerou por fazer ver a pessoa de Sócrates, o esmero de Platão não pôde ser distinto.
}

ALENCAR, Cesar de. A imagem do filósofo: o Teeteto de Platão e o método de Sócrates. Griot : Revista de Filosofia, Amargosa - BA, v.18, n.2, p.129-142, dezembro, 2018. 
mesmo que o professor, como se dá o processo de aprender. É sobre a maneira pela qual se dá o ato de aprendizado que um aluno, como Teeteto, tem autoridade para falar sobre.

Mas se aprender é tornar-se mais sábio a respeito do que se aprende ( $\tau$ ò $\mu \alpha v \theta \alpha ́ v \varepsilon ı v$

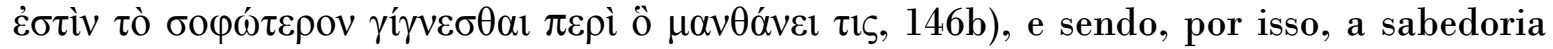

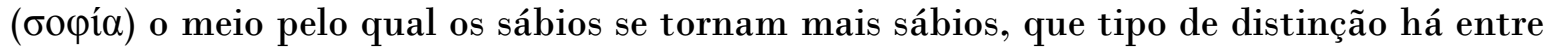
sabedoria e conhecimento? Por que razão a identificação entre sophía e epistéme incomoda Sócrates é algo que aqui não ficamos sabendo. Não surpreende, porém, que o impasse entre quem sabe e quem não sabe chegue a impor o problema de quem deve falar primeiro. Se Sócrates e Teeteto não são senão aparentados em seu não-saber, é de Teodoro que deve vir uma resposta. Sua esquiva, porém, é lapidar: não sendo habituado a esse tipo de discussão dialógica e já velho para aprendê-la (146b), é melhor que responda o mais moço. Teodoro não responde por ser incapaz de aprender, e a pergunta sobre o que seja a epistéme volta novamente para Teeteto. De algum modo, já desvinculadas sophía e epistéme, a resposta sobre o conhecimento deve se ater ao ambiente do aprender e do examinar. Essa distinção se esclarecerá depois, na descrição da sophía em meio à digressão sobre o filósofo.

\section{Teeteto ou A imagem da filosofia}

Velho demais para aprender a examinar por meio do diálogo, Teodoro cede lugar ao mais jovem, para quem essas coisas são mais fáceis. Facilidade para aprender é condição ao exame dialético. Sócrates, que já é velho, não cessa, porém, de aprender. Ou ele não sabe de fato o que seja isto, a epistéme, ou sua interrogação é irônica ${ }^{8}$. Sócrates negará ao júri de seu processo saber aquilo que lhe imputam. E não sendo sábio, como haveria de corromper os jovens com seus ensinamentos acerca de novas divindades? ${ }^{9}$ Sábio, diz ele aqui, é Teodoro, e por isso tem razão Teeteto ao responder, de entrada, que conhecimento é tudo aquilo que Teodoro ensina e coisas semelhantes (146c-d). Epistéme é, pois, entendida como aquilo que o mestre ensina ao seu aluno, aquilo que o aluno aprende de seu mestre. Sábio, portanto, é aquele capaz de ensinar, e quem ensina torna outros mais sábios naquilo que sabe. Teeteto ainda parece estar preso à identificação entre sophía e epistéme.

$\mathrm{O}$ conhecimento, pela resposta de Teeteto, não pode satisfazer à distinção socrática entre sophía e epistéme, porque focada ainda sob o aspecto da ação de saber, e não sobre o saber de fato. Sócrates não indaga sobre tipos de conhecimento, mas sobre o que é mesmo isso que chamamos de conhecimento. Não é possível falar de geometria ou de carpintaria como sendo conhecimentos, se não soubermos o que seja a epistéme ela

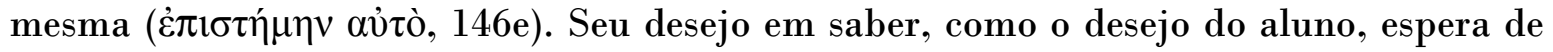
Teeteto uma resposta satisfatória, quer dizer, uma definição, como quando se define a lama não ao diferenciar-lhe os muitos tipos, mas ao defini-la como terra molhada (147c).

\footnotetext{
${ }^{8}$ Irônica aqui no sentido de VLASTOS, em ocultar saber (1991), p. 21-44 ${ }^{9}$ Cf. PLATÃ O, Apologia, 27d-e
}

ALENCAR, Cesar de. A imagem do filósofo: o Teeteto de Platão e o método de Sócrates. Griot : Revista de Filosofia, Amargosa-BA, v.18, n.2, p.129-142, dezembro, 2018. 
Definir é pôr em unidade a multiplicidade (148d), porém como poderia Teeteto oferecer definição como essa, das mais difíceis? Teodoro falhara em seu diagnóstico? Teeteto deixa-se vencer pelo corredor de pés mais velozes, como Sócrates (148c). A derrota em uma competição, porém, não anula o valor de quem acumulou vitórias. Teeteto havia muito bem resolvido a questão sobre as potências numa aula de Teodoro (147d-148b). Não haveria porque fraquejar diante deste desafio socrático.

Embora não esteja de imediato em condições de oferecer definição ao problema de Sócrates, ele sofre o que seriam dores de parto - a gestação de uma ideia que remói a alma por dentro, sem que veja a luz a não ser pela ajuda de uma parteira. Sócrates ajuda Teeteto, porque tal como sua mãe, ele é parteiro, o possuidor de uma arte ( $\tau \varepsilon ́ \chi v \eta v, 149$ a) em dar à luz ideias. A dinâmica que aproximou Sócrates e Teeteto, e que dizia respeito à natureza areté kai sophía de ambos, ganha uma diferença que justifica a posição de Sócrates como examinador: acerca do conhecimento, quem sabe o seu modo de ser é quem deve conduzir aquele que não sabe. Sócrates já não é mais um simples ignorante. Ele já está a ensinar alguma coisa.

De que espécie é esse seu saber obstétrico? As parteiras, já velhas para darem à luz, foram abençoadas pela deusa Ártemis com a faculdade de partejar ( $\mu \alpha \imath \varepsilon v ́ \varepsilon \sigma \theta \alpha \imath$ ), o que as torna capazes de identificar melhor que ninguém quando há gravidez, produzindo dores

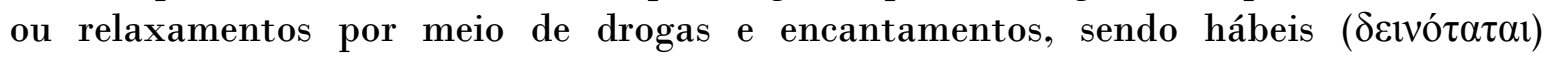

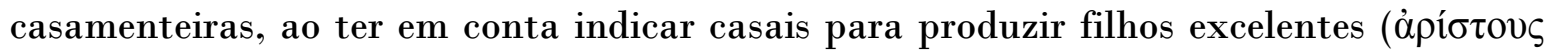
$\pi \alpha i \tilde{\delta} \alpha \varsigma, 149 \mathrm{~b}-\mathrm{e})$. A função das parteiras, dirá Sócrates, é inferior à sua, porque ele, além disso, tem condição de identificar os filhos verdadeiros e falsos (150c). O valor de sua tékhne está, por assim dizer, ao referir-se às almas jovens, no dizer-lhes se estão ou não na iminência de gerar frutos verdadeiros ou uma quimera. Uma arte divina como essa

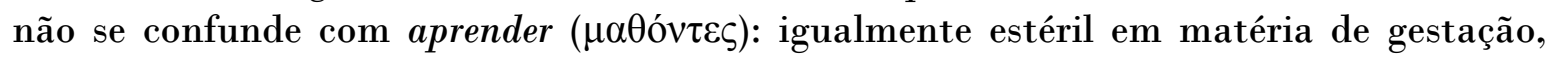
nada que se chega a saber pelo convívio com Sócrates é seu ensinamento, mas neles

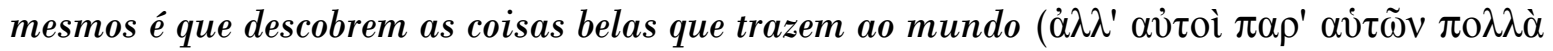

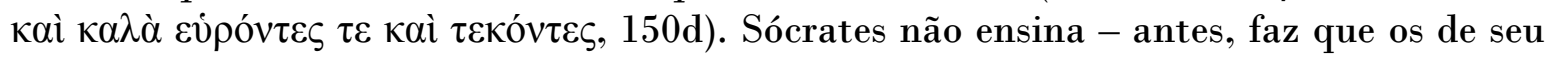
convívio descubram o saber.

A descrição minuciosa de sua atividade projeta luz à defesa apresentada no tribunal. Na Apologia, Sócrates defende-se da acusação anunciando nada saber, algo que ele sabia antes e que confirma após o exame dos que sabem, por ordenação divina ${ }^{10}$. Também aqui a defesa do não-saber chega a ser taxativa: por isso mesmo, não sou sábio, não havendo um só pensamento que eu possa apresentar como tendo sido invenção de minha

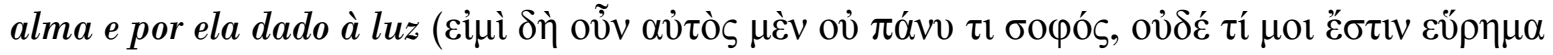

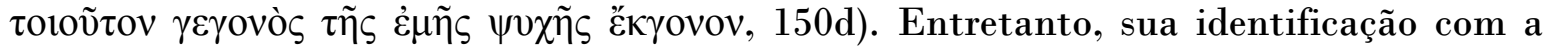
arte de partejar ideias nos deixa com a suspeita de que Sócrates aqui estaria privilegiando certos traços e ocultando outros: não fora ele mesmo quem disse proibir a deusa de possui tal tékhne quem nunca tivesse dado à luz, por ser fraca em demasia a

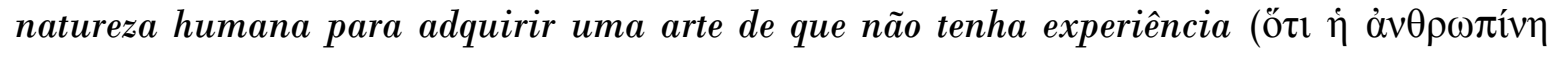

${ }^{10}$ Cf. PLATÃO, Apologia, 23b

ALENCAR, Cesar de. A imagem do filósofo: o Teeteto de Platão e o método de Sócrates. Griot : Revista de Filosofia, Amargosa-BA, v.18, n.2, p.129-142, dezembro, 2018. 


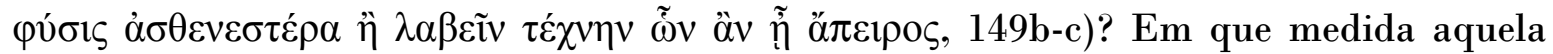
anthropíne sophía da qual ele se dissera possuidor na Apologia (20d) pode se identificar

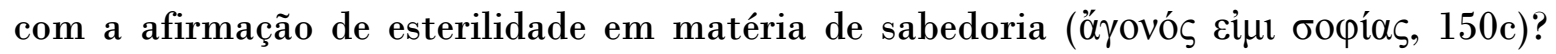
Não poderia ele ser como sua mãe que, já incapaz de gestar, lhe havia antes dado à luz? A que tipo de "Sócrates" Sócrates dera à luz?

É tentador não ver aqui o círculo vicioso que o texto parece trazer latente. Motivado pela busca de saber o que seja a epistéme, diversas vezes se torna espantoso que se deva, em alguma medida, saber algo sobre o conhecimento para ser possível saber o que ele é (por exemplo, em 144e; 147b; 165b; 186c; 187c; 188a-b). Mênon observou certa vez que a opinião erística repercutia o mesmo paradoxo ${ }^{11}$. 0 enigma do saber socrático, referido na Apologia - eu, como nada sei, nada julgo saber. E nisto parece-me que sou um

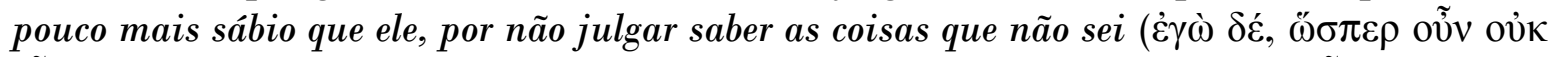

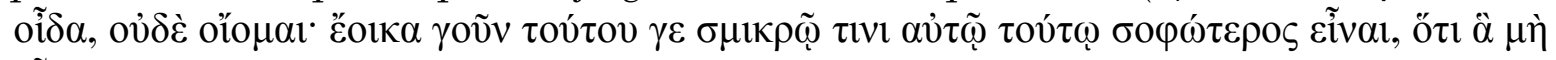

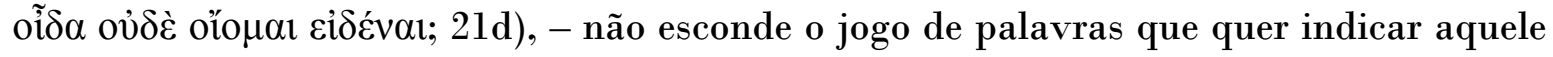

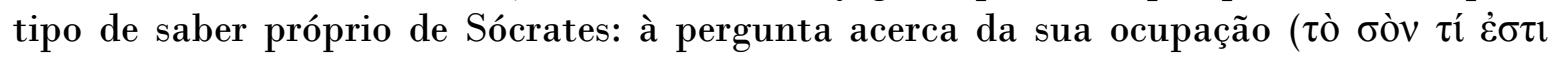

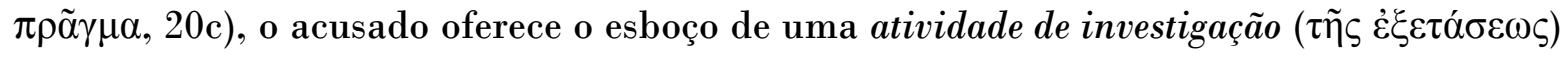
que não só lhe demonstrara o pouco ou nenhum valor da sabedoria humana, como ainda lhe ocupou o tempo a examinar outros para mostrar-lhes, a serviço divino, esta verdade $(23 \mathrm{a}-\mathbf{b})$.

Não há dúvidas de que Sócrates, na Apologia, identificou essa atividade de exame com o filosofar (28e; 29c-d). Contudo, o que em sua defesa foi exposto como atividade será no Teeteto descrito como um determinado tipo de saber: a philosophía. $\mathrm{O}$ substantivo que não aparecera no texto da Apologia surge aqui bem ao início, como um ramo de interesse de Sócrates, ao lado da geometria (143d). Sobre a philosophía, fala

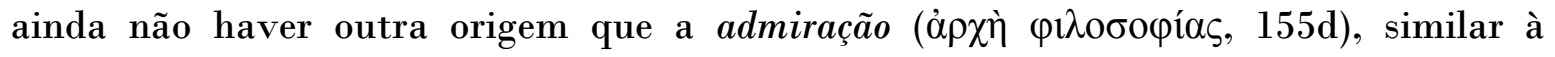
dificuldade que Sócrates refere a partir da sentença do deus de Delfos (Apologia, 21b). 0 próprio Sócrates volta a dizer não saber nada mais, exceto examinar outros, exceto filosofar (161b). Sendo fundamentalmente distinta da antilogía (164c), não faz discussão pura e simples, mas dialética ( $\delta \alpha \lambda \varepsilon \gamma o ́ \mu \varepsilon v o \varsigma, 168 a)$, e por isso os examinados, mostrandose seus amigos, acolherão a filosofia; por haver tantos que procedem em discussão, não em dialética, o número dos que se tornam inimigos da filosofia em idade avançada só tende a aumentar (168a-b).

Mas no Teeteto não se trata de examinar o pretenso saber de alguém que se diz um sábio, como seus interlocutores na narração da Apologia: o jovem Teeteto já confessara, de inicio, nada saber sobre a pergunta de Sócrates. A maiêutica, muito bem pontuou Benson ${ }^{12}$, é um tipo de técnica distinta daquela apresentada por Sócrates em sua defesa: ela almeja produzir no interlocutor não o sentimento final de aporia, provocado pelo sucessivo exame dialético, mas a disposição para investigar em conjunto

\footnotetext{
11 No Mênon (80d), a personagem título anuncia a Sócrates: "e de que modo procurarás, Sócrates, aquilo que não sabes absolutamente o que é?... Ou, ainda que, no melhor dos casos, a encontres, como saberás que isso é aquilo que não conhecias?".

12 BENSON (2012), p. 10-13
}

ALENCAR, Cesar de. A imagem do filósofo: o Teeteto de Platão e o método de Sócrates. Griot : Revista de Filosofia, Amargosa-BA, v.18, n.2, p.129-142, dezembro, 2018. 
a partir do assentimento inicial de estar em aporia ${ }^{13}$. Maiêutica e élenkhos são instrumentos diversos para fins filosóficos.

A prática da philosophía para o Sócrates da Apologia é a missão divina de purgar a alma da falsa ciência de que se sabe o que se ignora. É por ela que o réu se diz condenado. Junto a Teeteto, no entanto, Sócrates promove, pela dialética, outra forma de exame, em muito similar ao interrogatório do escravo no Mênon. Como diz Benson, não por acaso este é "o único diálogo estilisticamente [da fase] inicial em que um interlocutor é representado como engajado na busca em possuir o conhecimento a partir do reconhecimento de sua ignorância." (2012, p. 28). Pode-se dizer, com alguma segurança, que no Teeteto se trata de ensinar antes que de refutar: ou mais precisamente, esclarece Butti $^{14}$, de educar e não de persuadir, porque se trata aqui de homens livres e não de escravos, como são os erísticos.

\section{Sócrates ou 0 lugar da filosofia}

Sócrates, como vimos, referia ao filósofo não o procedimento erístico, as antilogias, mas o dialético, que se dá entre amigos na busca pelo saber. A descrição mais importante, contudo, sobre o filósofo no Teeteto encontra-se na assim chamada digressão. A imagem do filósofo em contraste com a do homem erístico reverbera uma nova dimensão do jogo de lusco-fusco pela dicotomia entre o risível e o sério. $O$ filósofo, que no seu desfrutar o ócio vê-se impossibilitado de discorrer em curto prazo sobre temas que movem seus interesses, e por esse motivo é tomado como incapaz de justificar sua causa se tiver de comparecer ao tribunal, tem sua incapacidade entendida como risível por quem, como a escrava trácia da anedota sobre Tales, está imerso nas coisas práticas (174c). O cidadão ordinário, no entanto, envolvido com coisas práticas e demandas materiais, é tido como ridículo pelo filósofo ao ter em alta conta coisas tão banais quanto os limites de terra e não a totalidade do ser, as causas jurídicas e não a justiça em si mesma. Aos olhos do filósofo, o orador não passa de um homem de alma pequena

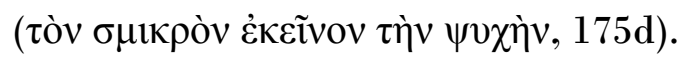

A situação da digressão nos apresenta características bastante sugestivas. Sócrates observa, após a autorrefutação oferecida pela defesa de Protágoras, precisar passar de um lógos curto a um longo (172b-c), ao que Teodoro responde não haver problema, pois eles dispõem de tempo livre ( $\sigma \chi 0 \lambda \eta े v)$. Se a referência ao tempo será à frente melhor percebida em sua significação política, aqui a prática do lógos mais longo pode causar estranheza, por não ser comum ao exercício dialético de Sócrates - ao menos, não ao Sócrates examinador da maior parte dos Diálogos da fase inicial de Platão. A face negativa, porém, não é a única que se vê adotar o Sócrates dos Diálogos:

\footnotetext{
13 VLASTOS havia indicado também uma distinção entre o élenkhos, que aparece nos Diálogos da fase inicial de Platão, e a forma dos argumentos no Teeteto, embora por razões de ordem argumentativa; ver (1991), p. 366.

${ }^{14}$ A dinâmica marcada pela dicotomia entre o homem livre e o escravo ganha sua significação na digressão de Sócrates acerca da condição do filósofo e a do homem ordinário na pólis, que será abordada na próxima seção; BUTTI (2004), p. 60-69
}

ALENCAR, Cesar de. A imagem do filósofo: o Teeteto de Platão e o método de Sócrates. Griot : Revista de Filosofia, Amargosa-BA, v.18, n.2, p.129-142, dezembro, 2018. 
o mestre de Platão, muitas vezes, dá vazão a uma dinâmica mais positiva do saber, aquilo que Benson apontou como uma defesa de posições (defense of positions) e que Vlastos reunia em um conjunto de crenças socráticas, de cunho moral, que pareciam ter sido obtidas por meio de autoexames refutatórios ${ }^{15}$. Se é assim, as teses positivas que Sócrates deixa transparecer em seu exercício dialético seriam o produto de sua própria gestação. A parteira precisa ter dado à luz seus próprios rebentos para ser capaz de auxiliar outros.

Dos elementos que a digressão do Teeteto nos traz acerca de quais possam ser aquelas teses morais que pertencem ao conjunto das ditas crenças socráticas, duas serão enfocadas aqui, pela proximidade com o tema desenvolvido: a primeira (a) diz respeito ao tempo livre ( $\sigma \chi 0 \lambda \eta े v)$ e à forma pela qual ele condiciona os modos de vida de ambos, do filósofo e do orador; a segunda (b) apresenta uma clara noção de o que seja a sabedoria e a verdade, o que não deixa de ser surpreendente a um texto cuja pretensão está em investigar o que é o saber. Se Sócrates tinha diferenciado sophía de epistéme ao início da discussão com Teeteto, parece que está na digressão a razão de ser desta diferenciação.

Sobre o tema de (a), a digressão toma de início a compreensão do ridículo ( $\gamma \varepsilon \lambda$ oĩou) de se mostrar orador ( $\rho$ í $\tau 0 \rho \varepsilon \varsigma)$, a defender sua causa nos tribunais, aquele que consome

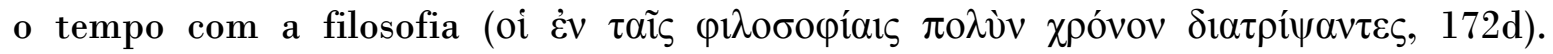
Sócrates introduz a descrição do filósofo, em contraste com o orador, a partir da ideia de tempo livre, que a imagem do tribunal evoca a servir paradigma ${ }^{16}$. $\mathrm{O}$ modo de proceder no tribunal, pautado pelo revide de injúrias sofridas, é o âmbito privilegiado da retórica como arte da persuasão, posto que se trata mesmo de saber dizer e contradizer o adversário a quem se ofende ou de quem se é vítima de ofensa (172e). O filósofo, de interesse posto nas coisas do alto, como Tales a contemplar os astros, só de corpo

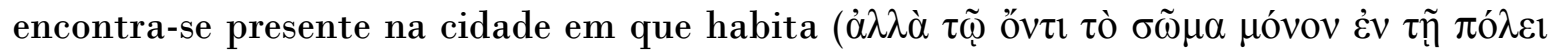

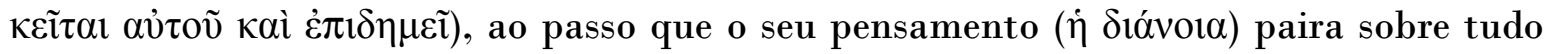

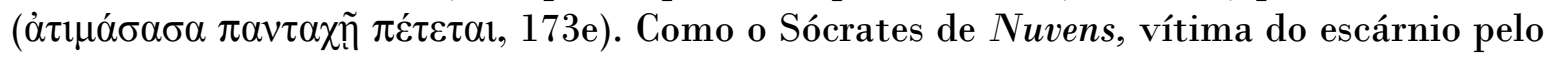
caráter de sua vida posta à parte aos assuntos da pólis, também o Sócrates de Apologia não deixou de levar em conta, naquela acusação, o tom apolítico com o qual era visto pelos seus juízes ${ }^{17}$.

Essa diferença de preocupações, que condiciona em última instância a diferença entre os dois modos de vida, o filosófico e o retórico, faz inverter o objeto da galhofa, em uma espécie de resposta filosófica acerca de sua condição. A quem tenha lido o texto da sua defesa em Apologia, não parecerá estranho que Sócrates procure remarcar, desde o início, a impossibilidade de apresentá-la nos moldes do tipo de discurso comum ao

${ }^{15}$ Cf. BENSON (2012), p. 26; VLASTOS (1994), seção III.

${ }^{16}$ Pode-se levantar a suspeita de que a imagem do tribunal esteja aqui a servir de modelo para acentua aquele paralelo com o julgamento de Sócrates a que nos referimos; mas no interior da discussão, à medida que o tema da digressão surge após a autorrefutação de Protágoras, a estratégia do modelo do tribunal soa como um recurso socrático em vista de ratificar em um tom mais forte a distinção entre o filósofo e o orador, ou entre Sócrates e Protágoras, se quisermos. É claro que ambas as leituras não se contradizem - antes, completam-se.

${ }^{17}$ Cf. PLATÃO, Apologia, 31b-e. Para o caráter apolítico do Sócrates em Nuvens, ver STRAUSS (1966).

ALENCAR, Cesar de. A imagem do filósofo: o Teeteto de Platão e o método de Sócrates. Griot : Revista de Filosofia, Amargosa-BA, v.18, n.2, p.129-142, dezembro, 2018. 
tribunal (17b-d). Não que Sócrates não conheça o tipo do discurso erístico e retórico: ele serve a propósitos distintos. O lógos retórico, esclarece Butti, é tido por território da nãoverdade, uma fuga da verdade a fim de agradar a maioria pela persuasão. Persuadir equivale a ter opiniões, e opinião não é conhecimento. Aquele que persuade faz o outro acreditar no que quer, e por isso não ensina de modo algum ${ }^{18}$. Não seria possível a Sócrates defender a verdade de seu ensino em um tribunal pelo recurso à verdade.

A violência da dominação que o orador exerce, por assim dizer, sobre o ouvinte volta-se, com efeito, sobre ele próprio, posto que sempre coagido pelo gosto de quem está a persuadir. Além do que está sempre posto contra o tempo, premido pela água da clepsidra, que o impede de se ater aos assuntos de que deseja tratar, tanto quanto o adversário, que lhe persegue uma prisão ao tema e ao tempo do dizer. A falta de tempo disponível e de liberdade para lidar com o assunto que lhe apraz torna o orador um escravo de alma retorcida, que acaba por se voltar, na fase adulta, para a mentira (173a). Sócrates não deve ser visto em Apologia como a desempenhar este papel: muito ao contrário, as sucessivas marcas que fez sobre a verdade do seu discurso têm como fundamento essa distinção em relação ao modo de ser retórico.

Se a verdade é esse fundamento que distingue o filósofo do orador, há que saber (b) o que ela seja. Sócrates não parece titubear, tanto no Teeteto quanto na Apologia, em

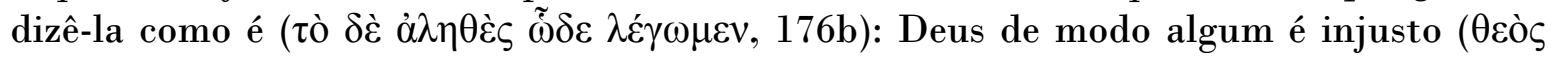

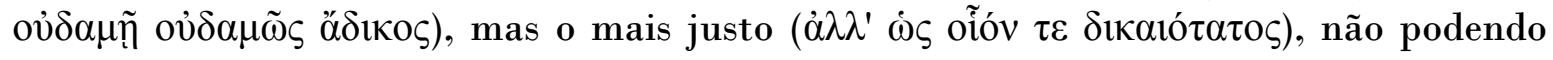

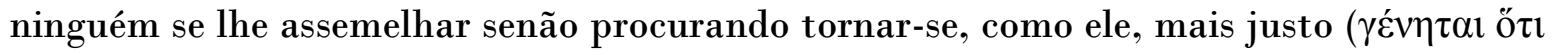

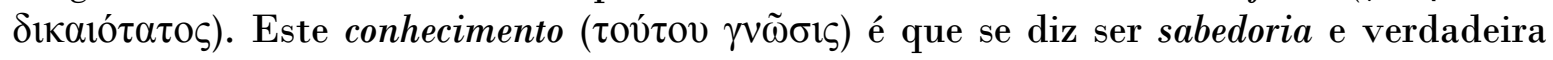

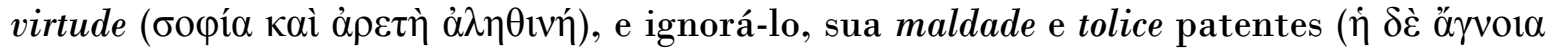

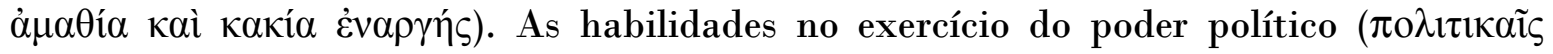

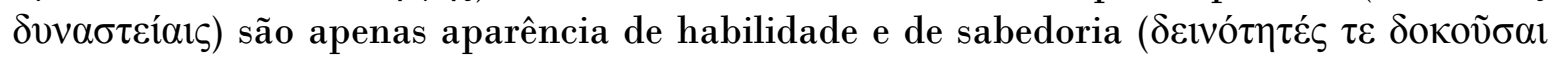

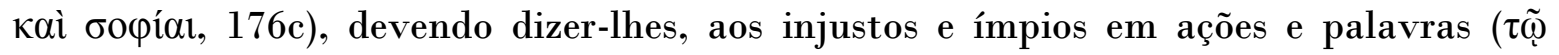

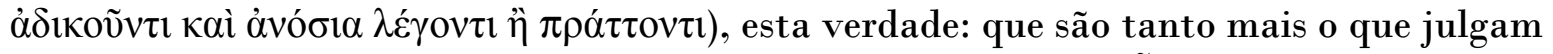

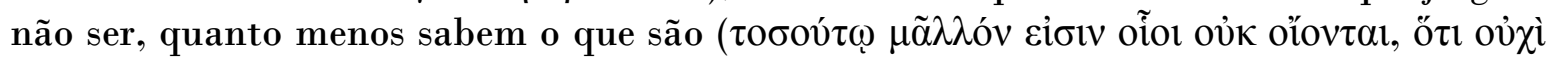

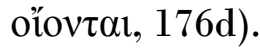

A dicotomia estabelecida entre o filósofo e o orador expressa não apenas modos distintos de dizer, em decorrência dos diferentes territórios em que se põem e das condições de tempo que os condicionam, mas também modos antagônicos de ser, haja vista os princípios de verdade e de falsidade que, respectivamente, lhes determinam as ações e os discursos. Os jovens, envolvidos pela retórica, chegam à fase adulta devotados à mentira. Não por acaso, Sócrates, velho que era, se recusou a falar como um menino em sua defesa (17d). Teeteto, ainda que jovem, fez-se amigo do saber e da verdade ao confessar não saber: a maiêutica socrática só pode atuar sobre a alma que está purgada de suas pretensões ao conhecimento. De algum modo, a maiêutica depende de um élenkhos que o antecede, e Platão parece demonstrá-lo no diálogo de Sócrates com Mênon. No Teeteto, porém, a busca em saber o que é o conhecimento só poderia mesmo

18 BUTTI (2004), p. 150-151

ALENCAR, Cesar de. A imagem do filósofo: o Teeteto de Platão e o método de Sócrates. Griot : Revista de Filosofia, Amargosa-BA, v.18, n.2, p.129-142, dezembro, 2018. 
se dar em um ambiente onde homens livres estão dispostos a percorrer um longo caminho, sem qualquer limitação de tempo ou de violência persuasiva. O filósofo, ao buscá-lo, mergulha no ridículo de gastar o seu tempo livre em contrariar o apreço dos homens. Seu exercício não demoraria a se transformar de ridículo em perigoso:

Esse homem pede a morte para mim. Seja. Que vos proporei em alternativa, Atenienses? É claro que proporei aquilo que mereço. Mas o quê? Que mereço eu pagar ou sofrer, por não ter aprendido a ficar quieto na vida, descurando aquilo com que as gentes se preocupam? (...) tentei persuadir cada um de vós a não cuidar primeiro das coisas da cidade, mas a cuidar antes da própria cidade, cuidando dos outros como de si próprios. Que merecerei eu sofrer por ser assim? (tradução de J. Trindade dos Santos - Apologia, 36c-d).

\section{Conclusão ou Sobre o conhecer}

Conhecimento é, por definição, conhecimento de algo, e saber o que é conhecimento em si mesmo é saber de que modo passamos de um estado de não-conhecer ao de conhecer. No fundo, a pergunta induz a que se tome o conhecimento como um processoe a resposta de Teeteto indica, de início, ser o conhecimento uma forma de percepção acerca do estado daquele que conhece (151e). É por esse motivo que a relação mestrealuno está na base da busca descrita no Teeteto. O não-saber do jovem aluno sobre o que seja conhecimento traz em germe a condição mesma para que possa vir à luz o que ele seja, porque não-saber é já uma forma de saber, mas é, sobretudo, o modo pelo qual se chega a saber o que não se sabe. $O$ filósofo, no fundo, está sempre aberto a aprender.

O processo, portanto, não pode ser percebido sem que se tenha já alguma noção do que seja saber. A distinção entre epistéme e sophía ganha aqui sua justificativa: é em vista da sophía que se põe em exame a epistéme. A digressão, que explicita o conteúdo decisivo da sophía como um princípio transcendente (o Deus que é o mais justo), transforma a arte socrática em uma pedra de toque na determinação do que seja ou não o conhecimento: quer seja no proceder por refutação (élenkhos), quer no avançar opiniões para que se descubra o saber em si mesmo (maiêutica), Sócrates está sempre opondo as opiniões sustentadas pelos seus interlocutores a um saber acerca do princípio transcendente que lhe deve fundamentar.

Por se tratar de conhecer o que é conhecer, nenhuma condição externa à alma deve forçá-la a perceber o que só nela mesma se dá. Aqui o aluno sozinho já não é capaz de ter em vista o processo do conhecimento, porque para ele o processo está condicionado àquela relação com o mestre. Por isso mesmo, Teeteto tinha por epistéme o que Teodoro ensinava-lhe. Era preciso que Sócrates, ao avançar as opiniões dos sábios (157c-d) a fim de lhe trazer à luz sua própria intelecção sobre a questão, direcionasse sua atenção para um objeto que não fosse o conteúdo do que ele aprendia com seu mestre, mas o próprio ato de aprender. Para isso, é preciso ver em si mesmo quando a alma

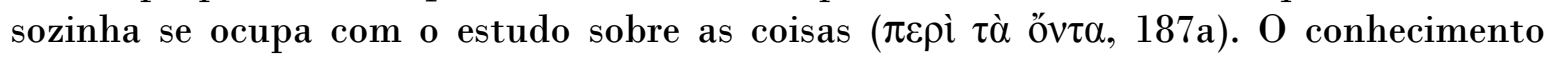
encerrará, com isso, a própria condição do aprendizado.

ALENCAR, Cesar de. A imagem do filósofo: o Teeteto de Platão e o método de Sócrates. Griot : Revista de Filosofia, Amargosa-BA, v.18, n.2, p.129-142, dezembro, 2018. 
Se aquilo que dissemos no início, quanto ao jogo do texto platônico em dizer e em fazer ver o que é dito, diz respeito aos quatro elementos do conhecimento, de um lado, e ao quinto, de outro, referidos na Carta VII, podemos entender a maiêutica socrática como um modo de fazer ver por uma forma de dizer: a dialética avançada contra a alma extrai dela suas falsas opiniões (élenkhos), que estão de certo modo no âmbito discursivo, para fazê-la inteligir (maiêutica) o que está para além do discurso, aquilo que o transcende.

É nesse sentido que a imagem do tribunal vem servir como um paradigma: o orador, ocupado em persuadir, atém-se ao discurso como meio para não ter que se ocupar com a justiça e a injustiça em si mesmas. A ele só interessam causas particulares e, a mercê delas, não passa de escravo das opiniões. $O$ filósofo, inexperiente quanto ao meio de se ocupar com causas particulares, tem sua visão direcionada ao que há de mais justo, ao que, por isso mesmo, transcende as opiniões em vista do saber. A sophía, como reconhecimento dessa verdade inteligida, traz a única possibilidade de o homem avaliar seus juízos em vista do conhecimento. Sócrates apresenta a filosofia como o percurso que o homem deve seguir, constantemente, ao remontar suas opiniões ao princípio inteligível que deve fundamentá-las. Não há saber que possa estar depositado nos quatro elementos discursivos, porque o saber é um ver antes de um dizer. O texto platônico, ao inspirar-se na busca socrática, sugere ao leitor a mesma busca, desde que estejamos postos como alunos a seguir o mestre maiêutico.

ALENCAR, Cesar de. A imagem do filósofo: o Teeteto de Platão e o método de Sócrates. Griot : Revista de Filosofia, Amargosa-BA, v.18, n.2, p.129-142, dezembro, 2018. 


\section{Referências}

AZEVEDO, M. T. S. Da maiêutica socrática à maiêutica platônica. Humanitas LV, p. 265-281, 2003.

BENSON, H. Plato's Socrates in the Theaetetus. Arquivo de rascunho disponível em www.ou.edu/ouphil/faculty/benson/benson.htm, 2012.

BURNYEAT, M. The Theaetetus of Plato. Indianapolis, Hackett P. C. 1990.

BUTTI, P. Platão: uma poética para a filosofia. São Paulo, Perspectiva. 2004.

GOLDSCHMIDT, V. Os diálogos de Platão. São Paulo, Loyola, 2002.

KAHN, C. H. Plato and The Socratic Dialogue. Cambridge, Cambridge U. P., 1994.

PLATÃo. Mênon. Tradução de Maura Iglesias. Rio de Janeiro, Ed. PUC - Rio; São Paulo, Loyola, 2001.

- Diálogos. Tradução de Carlos Alberto Nunes. Pará, EDUFPA, 2007a.

. Teeteto e Crátilo. Tradução de Carlos Alberto Nunes. Pará, EDUFPA, 2007b.

. Eutifron, Apologia de Sócrates e Críton. Tradução de José Trindade dos Santos.

Lisboa, INCM. 2007c.

- República. Tradução de Maria Helena da Rocha Pereira. Lisboa, Fundação

Calouste Gulbenkian, 2007b.

. Carta VII. Tradução de José Trindade dos Santos e Juvino Maia Jr. Rio de Janeiro, Ed. PUC-RIO; São Paulo, Loyola, 2008.

SALLIS, J. Being and Logos, The way of platonic dialogue. Pittsburgh, Duquesne U. P., 1975.

SZLÉZAK, T. Platão e a escritura da filosofia. São Paulo, Loyola.

VLASTOS, G., 2009.

. Socrates, Ironist and Moral Philosopher. New York, Cornell U. P., 1991.

. Socratic Studies. Cambridge, Cambridge U. P., 1994.

\section{Abreviaturas}

[DL] Diógenes Laércio. Vidas e doutrinas dos filósofos ilustres. Tradução e notas de Mário da Gama Kury. Brasília, UNB, 2008.

[SSR] Giannantoni, G. Socrates et Socraticorum Reliquae, 4 vols. (edição, introdução e notas) Nápoles, Bibliopolis, 1991.

Autor(a) para correspondência: Cesar de Alencar, Universidade Federal do Amapá, Departamento de Filosofia e Ciências, Rod. Juscelino Kubitschek, km 02 - Jardim Marco Zero, CEP 68903-419, Macapá AP,Brasil. cescama@gmail.com

ALENCAR, Cesar de. A imagem do filósofo: o Teeteto de Platão e o método de Sócrates. Griot : Revista de Filosofia, Amargosa-BA, v.18, n.2, p.129-142, dezembro, 2018. 